\title{
DECREASED SERUM LEVEL OF GAMMA-AMINO BUTYRIC ACID IN EGYPTIAN INFERTILE FEMALES WITH POLYCYSTIC OVARY SYNDROME IS CORRELATED WITH DYSLIPIDEMIA, TOTAL TESTOSTERONE AND 25(OH) VITAMIN D LEVELS
}

\section{SMANJEN SERUMSKI NIVO GAMA-AMINO BUTERNE KISELINE KOD NEPLODNIH ŽENA U EGIPTU SA SINDROMOM POLICISTICNIIH JAJNIKA JE U KORELACIJI SA DISLIPIDEMIJOM, UKUPNIM TESTOSTERONOM I 25(OH) VITAMINOM D}

\author{
Rasha A. Radwan 1, Nermeen Z. Abuelezz², Sahar M. Abdelraouf', \\ Engy M. Bakeer ${ }^{4}$, Abdullah A. Abd El Rahman ${ }^{5}$ \\ ${ }^{1}$ Biochemistry \& Biotechnology Department, Faculty of Pharmacy \& Drug Technology, Heliopolis University, Cairo, Egypt \\ ${ }^{2}$ Biochemistry Department, College of Pharmaceutical Sciences and Drug Manufacturing, \\ Misr University for Science and Technology, Giza, Egypt \\ ${ }^{3}$ Pharmacology and Toxicology Department, Faculty of Pharmacy, Misr International University, Cairo, Egypt \\ ${ }^{4}$ Faculty of Pharmacy, German University in Cairo, Cairo, Egypt \\ ${ }^{5}$ Obstetrics \& Gynecology Department, Faculty of Medicine Al-Azhar University, Cairo, Egypt
}

\section{Summary}

Background: Polycystic ovary syndrome (PCOS) is one of the most common female endocrine disorders around the world. Increasing evidence suggests that neurotransmitter Gamma-aminobutyric acid (GABA) is involved in the pathogenesis of PCOS through its central role in the hypothalamus. However, the peripheral role of GABA in PCOS has not been sufficiently investigated in spite of its existence in peripheral organs. First, the aim of this study is to, investigate serum GABA level in Egyptian PCOS patients. Second, to explore the correlation between serum GABA level with Body Mass Index (BMI), dyslipidemia, total testosterone and $25(\mathrm{OH})$ vitamin $\mathrm{D}$.

Methods: Eighty PCOS patients and eighty age-matched healthy females were included in this study. All parameters were assessed colourimetrically or with ELISA.

Results: PCOS patients exhibited significantly decreased serum GABA level compared to controls ( $p<0.001)$. There

\begin{abstract}
Kratak sadržaj
Uvod: Sindrom policističnih jajnika (PCOS) je jedan od najčešćih endokrinih poremećaja kod žena širom sveta. Sve više dokaza sugeriše da je neurotransmiter gamma-amino buterna kiselina (GABA) uključena u patogenezu PCOS na osnovu njene centralne uloge $u$ hipotalamusu. Međutim, periferna uloga GABA u PCOS nije dovoljno istražena uprkos njenom postojanju u perifernim organima. Cilj ove studije jeste da se prvo ispita serumski GABA nivo kod egipatskih PCOS pacijentkinja, a osim toga, potrebno je $\mathrm{i}$ istražiti korelaciju između nivoa GABA u serumu i indeksa telesne mase (BMI), dislipidemije, ukupnog testosterona i $25(\mathrm{OH})$ vitamina $D$.

Metode: U studiju je uključeno osamdeset pacijentkinja sa PCOS i osamdeset zdravih žena istog životnog doba. Svi parametri su procenjeni kolorimetrijskom ili ELISA metodom. Rezultati: Kod PCOS pacijentkinja se pokazao značajno sniženi nivo GABA u serumu u poređenju sa kontrolom grupom $(p<0,001)$. Postojala je značajna pozitivna korelacija između
\end{abstract}

Address for correspondence:

Rasha Ali Radwan

$5^{\text {th }}$ Al-Ansary street Heliopolis Cairo Egypt

Fax: 002-022-658-812-3

Mobile: 002-020-010-02045204

Phone number: 002-024-180-948

Work: 002-022-658-812-4

e-mail: rasha.radwan@hu.edu.eg
List of abbreviations: $\mathrm{AMH}$, anti Müllerian hormone; $\mathrm{BMI}$, body mass index, CSF, cerebrospinal fluid; Cyt. p450c: cytochrome p450-c17alpha-hydroxylase; FSH, follicle-stimulating hormone; GABA, gamma-aminobutyric acid; $\mathrm{GnRH}$, gonadotropin-releasing hormone; HDL-C, HDL cholesterol; HC, Hip circumference; LH, luteinizing hormone; IR, insulin resistance; LDL-C, LDL-cholesterol; OS, oxidative stress; PCOS, polycystic ovary syndrome; ROS, reactive oxygen species; TAG, triacylglycerol; TC, total cholesterol; WC, waist circumference 
was a significant positive correlation between serum GABA and $25(\mathrm{OH})$ vitamin $D$ levels $(r=0.26, p=0.018)$, and a significant negative correlation with total testosterone $(r=$ $0.3, p=0.02)$, total cholesterol $(\mathrm{TC})(r=-0.31, \mathrm{p}=0.01)$ and LDL-Cholesterol (LDL-C) $(r=-0.23, p=0.045)$, respectively.

Conclusions: The findings of this study suggest that disrupted GABA level in the peripheral circulation is an additional contributing factor to PCOS manifestations. GABA deficiency was correlated with $25(\mathrm{OH})$ vitamin D deficiency, dyslipidemia, and total testosterone. Further investigations for GABA adjustment might provide a promising means for better management of PCOS symptoms.

Keywords: PCOS, GABA, dyslipidemia, 25(OH) vitamin $D$, neuroendocrine

\section{Introduction}

Polycystic ovary syndrome (PCOS) is the most prevalent endocrine disorder among females of reproductive age (1), with the prevalence of 9-18\% all over the world and is the leading cause of infertility around the globe $(1,2)$. Moreover, the latest reports showed that PCOS prevalence exceeds $37 \%$ in secondary infertile Egyptian females especially in Upper Egypt (3). According to Rotterdam consensus, 2003, PCOS is diagnosed by having at least two of three main criteria; Oligo or anovulation, clinical or biochemical features of hyperandrogenism and polycystic ovaries on ultrasound examination (4). PCOS patients suffered from severe manifestations as infertility, hirsutism, acne, alopecia and disturbed hormonal profile. $(5,6)$. Moreover, PCOS is highly combined with insulin resistance (IR) $(7,8)$, dyslipidemia $(6,9)$ and obesity $(10)$. Heterogenic factors further contribute to PCOS manifestations (11).

PCOS was believed to be a mere ovarian disorder. Nevertheless, increasing basic and clinical research imply that disruption in the neuroendocrine homeostasis of the hypothalamus-pituitary-gonadal axis drives and contributes to PCOS $(12,13)$. Thereby in PCOS, there is an increased gonadotropinreleasing hormone $(\mathrm{GnRH})$ pulsatile secretion from the GnRH neuron network. This, in turn, causes significant disturbances in luteinizing hormone (LH), follicle-stimulating hormone (FSH) and progesterone levels. Moreover, it decreases hypothalamus sensitivity to progesterone negative feedback regulation. Such disruptions lead to increased androgen synthesis in the theca cells, causing anovulation, ovarian cysts, hirsutism and acne that are prevalent in PCOS (1416).

Recently, emerging evidence increasingly suggests a significant role for the neurotransmitter Gamma-aminobutyric acid (GABA) in PCOS. Recent animal model studies have shown that elevated androgen levels maintained PCOS by promoting central GABA secretion and activating central GABA- nivoa GABA i $25(\mathrm{OH})$ vitamina $\mathrm{D}$ u serumu $(r=0,26 ; p=$ $0,018)$ i značajne negativne korelacije sa ukupnim testosteronom ( $r=-0,3 ; p=0,02)$, ukupnim holesterolom (TC) $(r=-0,31 ; p=0,01)$ i LDL holesterolom (LDL - C) (r $=-0,23 ; p=0,045)$, respektivno.

Zaključak: Rezultati ove studije ukazuju na to da je poremećeni nivo GABA u perifernoj cirkulaciji dodatni faktor koji doprinosi manifestacijama PCOS. GABA je povezana sa $25(\mathrm{OH})$ vitaminom $\mathrm{D}$, dislipidemijom i testosteronom. Dalja istraživanja u vezi sa kontrolom GABA nivoa mogu doprineti boljoj kontroli simptoma PCOS-a.

Ključne reči: PCOS, GABA, dislipidemjia, 25(OH) vitamin $D$, neuroendokrini

ergic receptors stimulation to the neural $\mathrm{GnRH}$ cascade (17-19). Furthermore, Kawwass et al. (20) were the first to show that PCOS women exhibited high cerebrospinal fluid (CSF) GABA and total testosterone levels, supporting the central role hypothesis of GABA in PCOS. However, a small sample size, fluctuations in CSF analyses and not assessing serum GABA level were the main limitations in that study.

Interestingly, GABA and GABAergic receptors have been detected in various peripheral tissues as the ovaries, GIT, adrenal medulla and pancreas (21, 22). In the pancreas, adequate blood GABA levels activate GABA $A$ and GABA $B$ receptors, inducing calcium signalling and $A K T$ pathways which promote $B$ islets mass, decrease apoptosis and maintain healthy blood glucose level and proper insulin sensitivity (23). Whereas in the ovaries, GABA acts on the GABAergic receptors to maintain normal progesterone hormone secretion and corpus luteum formation (24) Regarding GIT and fat metabolism, GABA treatment exerts a powerful anti-inflammatory and antioxidant actions that significantly reduce macrophage infiltration in the adipose tissues and inhibit high fat-diet induced obesity (21). Consequently, further investigations are highly required to get a better understanding of GABA level in different biological fluids of PCOS patients.

It was reported that PCOS is characterized by the prevalence of obesity and disturbed levels of triacylglycerol (TAG) and total cholesterol (TC) (24). Interestingly, Ullah et al. (22) recently showed that administration of GABA significantly decreased dyslipidemia in PCOS animal model, which suggests a possible peripheral role for GABA level in PCOS. However, no studies investigated the levels of serum GABA and dyslipidemia in PCOS patients.

Moreover, testosterone, low serum 25(OH) vitamin D are also characteristic features in PCOS (6, $26)$. It is well documented that $25(\mathrm{OH})$ vitamin $D$ is a crucial player in follicular development, sensitivity to $\mathrm{FSH}$ and Anti-Müllerian hormone $(\mathrm{AMH})$ signalling 
(27). Remarkably, Groves et al. (28) found that $25(\mathrm{OH})$ vitamin $\mathrm{D}$ deficiency was associated with a disruption in GABA levels in the brain tissues of adult mice. In line with this, recent reports have shown that $25(\mathrm{OH})$ vitamin $\mathrm{D}$ deficiency could trigger depression through disturbances in neuronal calcium, glutamate and GABA concentrations (29). However, a correlation between GABA and $25(\mathrm{OH})$ vitamin D levels has not been explored in PCOS patients, either centrally or peripherally. In light of these observations, examining serum GABA levels in PCOS patients can provide a better understanding of its role in PCOS and whether this role is only limited to the CNS or extends to the peripheral organs through different mechanisms. To the best of our knowledge, no previous study examined serum GABA levels in PCOS patients, nor its relation to the biochemical and hormonal findings in PCOS patients.

Hence, we first aimed to investigate serum GABA level in Egyptian PCOS patients compared to healthy controls. Second, the aim was to explore the possible correlation between serum GABA level with body mass index (BMI), dyslipidemia, total testosterone and $25(\mathrm{OH})$ vitamin D levels in PCOS patients.

\section{Material and Methods}

\section{Study Population}

The present study included 2 main groups. Group 1 comprised 80 PCOS patients aged from 22 to 29 , with primary or secondary infertility as PCOS group. Diagnosis of PCOS was made according to Rotterdam consensus, 2003 (4). Where two out of the three following conditions were required to confirm PCOS diagnosis: Oligo- and/or anovulation, clinical and/or biochemical features of hyperandrogenism (defined by clinical hirsutism (FerrimanGallaway score 6), acne or alopecia and/or elevated androgens) and polycystic ovaries on ultrasound examination. Group 2 comprised 80 apparently healthy females aged from 22 to 30, as the Control group. All control females were apparently healthy, had regular cycles and had neither gynaecological nor endocrinal or neurological disorders.

Subjects having Cushing's syndrome, androgensecreting tumours, congenital adrenal hyperplasia, diabetes, immunological diseases, any form of malignancy and hyperprolactinemia were excluded from the study. None of the cases included in the study were smokers, nor did they receive oral contraceptive drugs. All subjects had stable body weight for at least 3 months. All subjects were recruited from the outpatient clinics of Al-Azhar University Teaching Hospitals all over Egypt. The study was performed after obtaining informed consent from all subjects and the approval of the ethics committee and the Review Board at Heliopolis University, Cairo, Egypt in accordance with The Code of Ethics of the Declaration of Helsinki.

\section{Sample Preparation}

Venous blood samples were collected by venipuncture after 12 hours overnight fasting. Blood was processed within 2 hours after collection and placed in a refrigerator for 1 hour, followed by centrifugation at $2000 \mathrm{~g}$ (3000 rpm) for 10 minutes at $4{ }^{\circ} \mathrm{C}$. The supernatant (serum) was separated and stored at $-80{ }^{\circ} \mathrm{C}$ until analysis.

\section{Laboratory Procedures}

Serum GABA level was measured using the Human Gamma-Aminobutyric Acid (GABA) ELISA Kit (MyBioSource, USA). 25-OH Vitamin D (total) level was detected by ELISA kit (DRG Instruments $\mathrm{GmbH}$, Germany). Serum total testosterone was measured by immunoassay (Architect 2nd Generation, Abbott Diagnostics, USA). All procedures were conducted according to the manufacturer's protocol. Serum TAG, TC and HDL-cholesterol (HDL-C) were determined using colourimetric enzymatic assay (Diamond Diagnostics, D-P international, Egypt). LDL- cholesterol (LDL- C) level was calculated using the Friedewalds formula:

$$
\mathrm{LDL}=\mathrm{T} \mathrm{C}-[(\mathrm{TAG} / 5)+\mathrm{HDL}-\mathrm{C}](30) \text {. }
$$

\section{Anthropometric Measurements}

Anthropometric measurements included body weight, height, mid-upper arm, thigh waist and hip circumferences and abdominal skinfold thickness. All measurements were taken 3 times on the left side of the body. Body weight was measured to the nearest $0.1 \mathrm{~kg}$ and height was measured to the nearest 0.1 $\mathrm{cm}$. Height was measured with patients standing with their backs leaning against the stadiometer of the same scale. BMI was calculated as weight in kilograms divided by height in square meters $\left(\mathrm{kg} / \mathrm{m}^{2}\right)$. Waist circumference (WC) and hip circumference (HC) were measured in $\mathrm{cm}$ using a plastic, nonstretchable tailor's tape. WC was measured with light clothing at a level midway between the lower rib margin and the iliac crest standing and breathing normally. $\mathrm{HC}$ was measured at the level at the widest circumference over the buttocks (at the greater trochanter). Skin-fold thickness was measured to the nearest $\mathrm{mm}$, except for low values (usually $5 \mathrm{~mm}$ or less) when it was taken to the nearest $0.5 \mathrm{~mm}$. Abdominal skin fold was at $5 \mathrm{~cm}$ adjacent to the umbilicus to the right side. Anthropometric measurements were obtained according to standardized equipment and following the recommendations of the International Biological Program. 


\section{Statistical Analysis}

Differences in variables between the two groups of the study were assessed using Mann Whitney's test. Continuous data was presented as a median and interquartile range. Spearman's Correlation was done to detect the presence, degree and direction of the association between the measured variables in PCOS patients. For all data, $p$ value of $<0.05$ (two-tailed) was considered significant. Statistical analysis were performed using the SPSS package (version 23 for Windows; SPSS Inc., Chicago, IL, USA).

\section{Results}

Biochemical and hormonal data in PCOS and Controls

Patients with PCOS and normal controls did not differ significantly in age. PCOS patients showed significantly higher BMI, serum TAG, TC and LDL-C levels compared to healthy controls ( $p<0.001)$ whereas serum HDL-C was significantly lower in PCOS in comparison to controls ( $<<0.001$ ). A detailed description of the demographic and biochemical characteristics of both groups are shown in Table 1 .

PCOS group showed significantly lower GABA levels and significantly higher serum total testosterone levels compared to healthy controls ( $p<0.001)$. Moreover, PCOS had significantly lower serum $25(\mathrm{OH})$ vitamin $D$ level compared to the control group $(p<0.001)$. Detailed data on serum GABA and hormonal profile are shown in Table II.

Table I Demographic and biochemical characteristics of PCOS group vs. normal controls. Data are presented as a median and interquartile range.

\begin{tabular}{|l|c|c|c|}
\hline Parameters & $\begin{array}{c}\text { PCOS } \\
\mathrm{N}=80\end{array}$ & $\begin{array}{c}\text { Control } \\
\mathrm{N}=80\end{array}$ & $\begin{array}{c}\mathrm{p} \\
\text { Value }\end{array}$ \\
\hline $\begin{array}{l}\text { Age } \\
\text { (years) }\end{array}$ & $\begin{array}{c}26 \\
(25-27)\end{array}$ & $\begin{array}{c}25 \\
(24-27)\end{array}$ & 0.9 \\
\hline $\begin{array}{l}\mathrm{BMI} \\
\mathrm{kg} / \mathrm{m}^{2}\end{array}$ & $\begin{array}{c}26.3 \\
(24-28.3)\end{array}$ & $\begin{array}{c}23.33 \\
(22.5-25.8)\end{array}$ & $<0.001^{*}$ \\
\hline $\begin{array}{l}\mathrm{TAG} \\
\mathrm{mmol} / \mathrm{L}\end{array}$ & $\begin{array}{c}2.56 \\
(2.37-2.8)\end{array}$ & $\begin{array}{c}1.4 \\
(1.32-1.54)\end{array}$ & $<0.001^{*}$ \\
\hline $\begin{array}{l}\mathrm{TC} \\
\mathrm{mmol} / \mathrm{L}\end{array}$ & $\begin{array}{c}5.45 \\
(5.21-5.7)\end{array}$ & $\begin{array}{c}4.1 \\
(3.9-4.23)\end{array}$ & $<0.001^{*}$ \\
\hline $\begin{array}{l}\mathrm{LDL}-\mathrm{C} \\
\mathrm{mmol} / \mathrm{L}\end{array}$ & $\begin{array}{c}3.83 \\
(3.59-4.06)\end{array}$ & $\begin{array}{c}2.2 \\
(1.97-2.33)\end{array}$ & $<0.001^{*}$ \\
\hline $\begin{array}{l}\mathrm{HDL}-\mathrm{C} \\
\mathrm{mmol} / \mathrm{L}\end{array}$ & $\begin{array}{c}1.13 \\
(1-1.23)\end{array}$ & $\begin{array}{c}1.7 \\
(1.5-1.73)\end{array}$ & $<0.001 *$ \\
\hline
\end{tabular}

*indicates significant difference at $p$ value $<0.05$.
Table II Serum GABA level, testosterone and 25(OH) vitamin D of PCOS group vs. normal controls. Data are presented as median and interquartile range.

\begin{tabular}{|l|c|c|l|}
\hline Parameters & $\begin{array}{c}\text { PCOS } \\
\mathrm{N}=80\end{array}$ & $\begin{array}{c}\text { Controls } \\
\mathrm{N}=80\end{array}$ & $\mathrm{p}$ Value \\
\hline $\begin{array}{l}\text { GABA } \\
(\mu \mathrm{mol} / \mathrm{L})\end{array}$ & $\begin{array}{c}1.95 \\
(1.3-2.57)\end{array}$ & $\begin{array}{c}4.3 \\
(3.7-5.25)\end{array}$ & $<0.001 *$ \\
\hline $\begin{array}{l}\text { Testosterone } \\
(\mathrm{nmol} / \mathrm{L})\end{array}$ & $\begin{array}{c}4.7 \\
(3.9-4.9)\end{array}$ & $\begin{array}{c}0.6 \\
(0.42-0.7)\end{array}$ & $<0.001 *$ \\
\hline $\begin{array}{l}\text { Vitamin D } \\
(\mathrm{nmol} / \mathrm{L})\end{array}$ & $\begin{array}{c}38.5 \\
(33.51-43.75)\end{array}$ & $\begin{array}{c}77.5 \\
(63.05-90.2)\end{array}$ & $<0.001 *$ \\
\hline
\end{tabular}

*indicates significant difference at $p$ value $<0.05$.

Correlation between different biochemical and hormonal data in PCOS group

The correlation was investigated between different measured parameters in PCOS group and serum GABA levels. There was a statistically significant positive correlation between serum GABA and $25(\mathrm{OH})$ vitamin $D$ levels $(r=0.26, p=0.018)$ and a statistically significant negative correlation with serum total testosterone level $(r=-0.3, p=0.02)$. Moreover, GABA level was significantly negatively correlated with TC $(r=-0.31, p=0.01)$ and LDL-C $(r=-0.23, p=0.045)$ levels, respectively. However, there was no statistically significant correlation with BMI, TAG and HDL-C.

\section{Discussion}

In the present study, we aimed to investigate serum GABA level in Egyptian PCOS patients and explore its relation to $\mathrm{BMI}$ and biochemical characteristics of PCOS patients. PCOS patients showed significantly higher BMI, TAG, TC, LDL-C levels and significantly lower HDL-C levels compared to agematched healthy females. Such findings agree with the previously documented findings of $\operatorname{PCOS}(6,31-$ 33). Moreover, dyslipidemia is highly prevalent and reported even in lean PCOS females (34).

Serum GABA level was significantly decreased in PCOS subjects compared to healthy controls. However, Kawwass et al. (20) observed significant high levels of GABA in the CSF of PCOS women compared to healthy controls. Additionally, patients who take valproate antiepileptic drugs to induce GABAergic tone in the brain, usually show PCOS like symptoms $(35,36)$. It is worth mentioning here that the inversed level of neurotransmitters and biomarkers between CSF and other biological fluids is a well-known phenomenon. It can be explained by differences in neuronal uptake, changes in production, metabolism and clearance in different tissues, which lead to accumulation in the brain and CSF while decreasing in plasma and serum (37). 
In the present study, there was a statistically significant negative correlation between serum GABA and total testosterone levels. This goes in line with a recent rat model study, where oral GABA intake had an obvious anti-androgenic effect that was demonstrated by significantly decreasing serum total testosterone level and reduced formation of ovarian cysts (22). Furthermore, it has been documented that IR causes hyperandrogenism by stimulating the enzyme cytochrome p450-c17alpha-hydroxylase (cyt. p450c). Any slight disturbance in the factors responsible for the up and down-regulation of cyt. $\mathrm{p} 450 \mathrm{c}$ in theca cells, may cause ovarian hyperandrogenism despite normal LH secretion $(38,39)$. Moreover, IR potentiates the effects of LH on thecainterstitial cells, resulting in increased androgen production while arresting the follicular maturation process which leads to PCOS $(40,41)$. On the other hand, treatment with GABA is reported to improve insulin sensitivity through its peripheral receptors in the pancreas, ovaries and adrenal medulla in animal models $(21,42)$. Consequently, this might reduce androgen synthesis by the ovarian theca cells, as IR is a critical contributing factor in excess androgen secretion (43).

Recently, oxidative stress (OS) has been documented in infertile women with PCOS (44-46). It has been demonstrated to be directly correlated with total testosterone and androstenedione which may, as a result, contribute to hyperandrogenism in PCOS women. Furthermore, OS is involved in altered steroidogenesis in the ovaries, thus contributing to increased androgen production, disturbed follicular development and, ultimately infertility $(47,48)$. Moreover, it has been shown that OS correlates with IR (48). Interestingly, it was reported that GABA recovered the activities of several antioxidant enzymes in letrozole induced PCOS model (22). Furthermore, GABA has been reported as a positive regulator of antioxidant enzymes as it reduces reactive oxygen species (ROS), so it maintains tissue protection, regeneration in addition to normoglycemia in humans and animals. Hence, counteracts both OS and IR $(23,50,51)$.

Interestingly, we found a significant positive correlation between serum GABA and $25(\mathrm{OH})$ vitamin D levels in PCOS patients. Recent studies are increasingly pointing out the possible link between $25(\mathrm{OH})$ vitamin D and GABA. Groves et al. (28) reported that $25(\mathrm{OH})$ vitamin $D$ deficient mice showed disruptions in GABA level and GABA synthesizing enzymes in the brain tissues, leading to behavioural and neurochemical alterations. Additionally, deficiency of Vitamin $D$ has been linked to poor GABA production and blood levels in humans (52). The findings of our study support this hypothesis and imply the possible role of both GABA and $25(\mathrm{OH})$ vitamin $D$ alterations in PCOS manifestations both peripherally and centrally. Moreover, disrupted levels of both GABA and $25(\mathrm{OH})$ vitamin D levels in PCOS, can contribute to the impaired emotional and cognitive issues prevalent among PCOS patients (29, 53). Further investigations are needed to confirm this assumption.

In the current investigation, a significant negative correlation between serum GABA level and TC and LDL-C levels. There is a strong association between dyslipidemia observed in PCOS and IR (8, 25). Meanwhile, recent studies reported that pancreatic islets secrete GABA which has multiple effects on $B$ cells through increasing insulin secretion, stimulating cell proliferation and tissue regeneration $(54,55)$. In line with these studies, GABA intake was reported to significantly improve the lipid profile of letrozole-induced PCOS rats (22). Moreover, GABA has been reported to be involved in reducing $\mathrm{TC}$ in humans $(50,51)$. Furthermore, GABA is reported to maintain adequate lipid profile in humans and animals $(23,51)$. Such an effect may be attributed to the protective role of GABA on glucose homeostasis and antioxidant enzymes, improving overall insulin sensitivity (22).

In conclusion, Egyptian PCOS patients showed significantly low serum GABA levels compared to healthy controls. This impairment was significantly correlated with dyslipidemia and $25(\mathrm{OH})$ vitamin D deficiency and serum total testosterone level. The findings of the present study strongly suggest that the disrupted GABA level in the peripheral circulation of PCOS patients contribute to PCOS manifestations, mostly through lack of the ability of improvement of IR and its deficient antioxidant potential. Further investigations of serum GABA antioxidant potential together with IR on different populations can provide a promising means for better management of PCOS symptoms.

Acknowledgements. No acknowledgements to be made and no funding source to be acknowledged.

\section{Conflict of interest statement}

The authors stated that they have no conflicts of interest regarding the publication of this article. 


\section{References}

1. March WA, Moore VM, Willson KJ, Phillips DIW, Norman RJ, Davies MJ. The prevalence of polycystic ovary syndrome in a community sample assessed under contrasting diagnostic criteria. Hum Reprod Oxf Engl 2010; 25: 544-51.

2. Padmanabhan V. Polycystic Ovary Syndrome - »A Riddle Wrapped in a Mystery inside an Enigma." J Clin Endocrinol Metab 2009; 94: 1883-5.

3. Sanad AS. Prevalence of polycystic ovary syndrome among fertile and infertile women in Minia Governorate, Egypt. Int J Gynaecol Obstet 2014; 125: 81-2.

4. Rotterdam EA. Revised 2003 consensus on diagnostic criteria and long-term health risks related to polycystic ovary syndrome. Fertil Steril 2004; 81(1): 19-25.

5. Ding T, Hardiman PJ, Petersen I, Wang F-F, Qu F, Baio G. The prevalence of polycystic ovary syndrome in reproductive-aged women of different ethnicity: a systematic review and meta-analysis. Oncotarget 2017; 8: 963518.

6. Bakeer E, Radwan R, Mandoury AE, Rahman AAE, Gad M, Maksoud SAE. Anti-Müllerian Hormone as a Diagnostic Marker in Egyptian Infertile Polycystic Ovary Syndrome Females: Correlations with Vitamin D, Total Testosterone, Dyslipidemia and Anthropometric Parameters. J Med Biochem 2018; 37: 448-55.

7. Hart R, Hickey M, Franks S. Definitions, prevalence and symptoms of polycystic ovaries and polycystic ovary syndrome. Best Pract Res Clin Obstet Gynaecol 2004; 18: 671-83.

8. Dunaif A. Insulin resistance and the polycystic ovary syndrome: mechanism and implications for pathogenesis. Endocr Rev 1997; 18: 774-800.

9. Vidya Bharathi R, Swetha S, Neerajaa J, Varsha Madhavica J, Janani DM, Rekha SN, et al. An epidemiological survey: Effect of predisposing factors for PCOS in Indian urban and rural population. Middle East Fertil Soc J 2017; 22: 313-6.

10. Thomali Al A, Daghestrani HM, Daghestani HM, Kaya N, Warsy A. Polymorphic Variations in VDR Gene in Saudi Women with and Without Polycystic Ovary Syndrome (PCOS) and Significant Influence of Seven Polymorphic Sites on Anthropometric And Hormonal Parameters. J Med Biochem 2018; 37; 415-25.

11. Moore AM, Campbell RE. Polycystic ovary syndrome: Understanding the role of the brain. Front Neuroendocrinol 2017; 46: 1-14.

12. Hu M, Richard JE, Maliqueo M, Kokosar M, Fornes R, Benrick $A$, et al. Maternal testosterone exposure increases anxiety-like behavior and impacts the limbic system in the offspring. Proc Natl Acad Sci USA 2015; 112: 14348-53.

13. Moore AM, Campbell RE. The neuroendocrine genesis of polycystic ovary syndrome: A role for arcuate nucleus GABA neurons. J Steroid Biochem Mol Biol 2016; 160: 106-17.

14. Jonard S, Dewailly D. The follicular excess in polycystic ovaries, due to intra-ovarian hyperandrogenism, may be the main culprit for the follicular arrest. Hum Reprod Update 2004; 10: 107-17.

15. Yoo RY, Dewan A, Basu R, Newfield R, Gottschalk M, Chang RJ. Increased luteinizing hormone pulse frequency in obese oligomenorrheic girls with no evidence of hyperandrogenism. Fertil Steril 2006; 85: 1049-56.

16. Taylor AE, McCourt B, Martin KA, Anderson EJ, Adams $J M$, Schoenfeld $D$, et al. Determinants of abnormal gonadotropin secretion in clinically defined women with polycystic ovary syndrome. J Clin Endocrinol Metab 1997; 82: 2248-56.

17. Penatti CAA, Davis MC, Porter DM, Henderson LP. Altered GABA A receptor-mediated synaptic transmission disrupts the firing of gonadotropin-releasing hormone neurons in male mice under conditions that mimic steroid abuse. J Neurosci 2010; 30: 6497-506.

18. Jansen HT, Hershey J, Mytinger A, Foster DL, Padmanabhan V. Developmental Programming: Reproductive Endocrinopathies in the Adult Female Sheep After Prenatal Testosterone Treatment Are Reflected in Altered Ontogeny of GnRH Afferents. Endocrinol 2011; 152: 4288-97.

19. Moore AM, Prescott M, Marshall CJ, Yip SH, Campbell RE. Enhancement of a robust arcuate GABAergic input to gonadotropin-releasing hormone neurons in a model of polycystic ovarian syndrome. Proc Natl Acad Sci USA 2015; 112: 596-601.

20. Kawwass JF, Sanders KM, Loucks TL, Rohan LC, Berga SL. Increased cerebrospinal fluid levels of GABA, testosterone and estradiol in women with polycystic ovary syndrome. Hum Reprod Oxf Engl 2017; 32: 1450-6.

21. Tian J, Dang H, Kaufman DL. Combining antigen-based therapy with GABA treatment synergistically prolongs survival of transplanted B-cells in diabetic NOD mice. Plos One 2011; 6: e25337.

22. Ullah A, Jahan S, Razak S, Pirzada M, Ullah H, Almajwal $A$, et al. Protective effects of GABA against metabolic and reproductive disturbances in letrozole induced polycystic ovarian syndrome in rats. J Ovarian Res 2017; 10: 6270.

23. Purwana I, Zheng J, Li X, Deurloo M, Son DO, Zhang $Z$, Liang $C$, Shen E, et al. GABA promotes human $\beta$-cell proliferation and modulates glucose homeostasis. Diabetes 2014; 63(12): 4197-205.

24. Rapkin A and Akopians A Pathophysiology of premenstrual syndrome and premenstrual dysphoric disorder. Menopause Int 2012; 18(2): 52-9.

25. Barthelmess EK, Naz RK. Polycystic ovary syndrome: current status and future perspective. Front Biosci Elite Ed 2014; 6: 104-19.

26. Thomson RL, Spedding S, Buckley JD. Vitamin D in the etiology and management of polycystic ovary syndrome. Clin Endocrinol (Oxf) 2012; 77: 343-50.

27. Irani $M$, Merhi Z. Role of vitamin D in ovarian physiology and its implication in reproduction: a systematic review. Fertil Steril 2014; 102: 460-8.e3. 
28. Groves NJ, Kesby JP, Eyles DW, McGrath JJ, Mackay-Sim A, Burne THJ. Adult vitamin D deficiency leads to behavioural and brain neurochemical alterations in C57BL/6J and BALB/c mice. Behav Brain Res 2013; 241: 120-31.

29. Berridge MJ, Vitamin D and Depression: Cellular and Regulatory Mechanisms. Pharmacological Reviews April 2017; 69 (2): 80-92.

30. Fukuyama N, Homma K, Wakana N, Kudo K, Suyama A, Ohazama $\mathrm{H}$, et al. Validation of the Friedewald Equation for Evaluation of Plasma LDL-Cholesterol. J Clin Biochem Nutr 2008; 43(1): 1-5.

31. Perović Blagojević I, Ignjatović S, Macut Dj, KoturStevuljević J, Božić-Antić I, Vekić J, Bjekić-Macut J, Kastratović Kotlica B, Andrić Z, Ilić D. Evaluation of a Summary Score for Dyslipidemia, Oxidative Stress and Inflammation (The Doi Score) in Women with Polycystic Ovary Syndrome and its Relationship with Obesity. J Med Biochem 2018; 37: 476-85.

32. Wild RA, Rizzo M, Clifton S, Carmina E. Lipid levels in polycystic ovary syndrome: systematic review and metaanalysis. Fertil Steril 2011; 95: 1073-9. e1-11.

33. Kim JJ, Choi YM. Dyslipidemia in women with polycystic ovary syndrome. Obstet Gynecol Sci 2013; 56: 137-42.

34. Goodman NF, Cobin RH, Futterweit W, Glueck JS, Legro RS, Carmina E. American association of clinical endocrinologists, American college of endocrinology, and androgen excess and pcos society disease state clinical review: a guide to the best practices in the evaluation and treatment of polycystic ovary syndrome - part 2. Endocr Pract 2015; 21: 1415-26.

35. Bilo L, Meo R. Polycystic ovary syndrome in women using valproate: a review. Gynecol Endocrinol 2008; 24: 56270 .

36. Hu X, Wang J, Dong W, Fang Q, Hu L, Liu C. A metaanalysis of polycystic ovary syndrome in women taking valproate for epilepsy. Epilepsy Res 2011; 97: 73-82.

37. Cosín-Tomás M, Antonell A, Lladó A, Alcolea D, Fortea J, Ezquerra $M$, et al. Plasma miR-34a-5p and miR-545-3p as Early Biomarkers of Alzheimer's Disease: Potential and Limitations. Mol Neurobiol 2017; 54: 5550-62.

38. Galluzzo A, Amato MC, Giordano C. Insulin resistance and polycystic ovary syndrome. Nutr Metab Cardiovasc Dis 2008; 18: 511-8.

39. Nisenblat $\bigvee$, Norman RJ. Androgens and polycystic ovary syndrome. Curr Opin Endocrinol Diabetes Obes 2009; 16: 224-31.

40. Baptiste CG, Battista MC, Trottier A, Baillargeon JP. Insulin and hyperandrogenism in women with polycystic ovary syndrome. J Steroid Biochem Mol Biol 2010; 122: 42-52.

41. Gambineri A, Patton L, Prontera O, Fanelli F, Ciampaglia W, Cognigni GE, et al. Basal insulin-like factor 3 levels predict functional ovarian hyperandrogenism in the polycystic ovary syndrome. J Endocrinol Investig 2011; 34: 685-91.

42. Soltani N, Qiu, H, Aleksic M, Glinka Y, Zhao F, Liu R, et al. GABA exerts protective and regenerative effects on islet beta cells and reverses diabetes. Proceedings of the National Academy of Sciences of the United States of America 2011; 108(28): 11692-7.

43. Asagami T, Holmes TH, Reaven G. Differential Effects of Insulin Sensitivity on Androgens in Obese Women with Polycystic Ovary Syndrome or Normal Ovulation. Metabolism: clinical and experimental 2008; 57: 1355-60.

44. Agarwal A, Gupta S, Sharma RK. Role of oxidative stress in female reproduction. Reprod Biol Endocrinol 2005; 14: 3-28.

45. Gonzalez F, Rote NS, Minium J, Kirwan JP. Reactive oxygen species-induced oxidative stress in the development of insulin resistance and hyperandrogenism in polycystic ovary syndrome. J Clin Endocrinol Metab 2006; 91: 336-40.

46. Verit FF, Erel O. Oxidative stress in non-obese women with polycystic ovary syndrome: correlations with endocrine and screening parameters. Gynecol Obstet Investig 2008; 65: 233-9.

47. Kuscu NK, Var A. Oxidative stress but not endothelial dysfunction exists in non-obese, young group of patients with polycystic ovary syndrome. Acta Obstet Gynecol Scand 2009; 88: 612-7.

48. Kandasamy S, Sivagamasundari RI, Bupathy A, Sethubathy S, Gobal V. Evaluation of insulin resistance and oxidative stress in obese patients with polycystic ovary syndrome. Int J Appl Biol Pharm Technol 2010; 1: 391-7.

49. Kurdoglu Z, Ozkol H, Tuluce Y, Koyuncu I. Oxidative status and its relation with insulin resistance in young non-obese women with polycystic ovary syndrome. J Endocrinol Investig 2011; 26: 134-42.

50. Tian J, Chau C, Hales TG, Kaufman DL. GABA (A) receptors mediate inhibition of $T$ cell responses. J Neuroimmunol 1999; 96(1): 21-8.

51. Reyes-García MG, Hernández-Hernández F, Hernández-Téllez B, García-Tamayo F. GABA (A) receptor subunits RNA expression in mice peritoneal macrophages modulate their IL-6/IL-12 production. J Neuroimmunol 2007; 188(1): 64-8.

52. Hong AR, Kim YA, Bae JH, Min HS, Kim JH, Shin CS, et al. A Possible Link between Parathyroid Hormone Secretion and Local Regulation of GABA in Human Parathyroid Adenomas. J Clin Endocrinol Metab 2016; 101: 2594-601.

53. Balikci A, Erdem M, Akarsu S, Keskin U, Ztosun M, Zincir Sb, et al. Depression, Anxiety, and Anger in Patients with Polycystic Ovary Syndrome. Archives of Neuropsychiatry 2014; 51: 328-33.

54. Wan Y, Wang Q, Prud'homme GJ. GABAergic system in the endocrine pancreas: a new target for diabetes treatment. Diabetes Metab Syndr Obes Targets Ther 2015; 8: 79-87.

55. Fiorina P. GABAergic System in $\beta$-Cells: From Autoimmunity Target to Regeneration Tool. Diabetes 2013; 62: 3674-6. 